EGU Stephan Mueller Special Publication Series, 3, 217-226, 2002

(C) European Geosciences Union 2002

\title{
Analogue modelling of a prograding strike-slip fault: Case study of the Balatonfó fault, western Hungary
}

\author{
G. Lopes Cardozo ${ }^{1}$, G. Bada ${ }^{2}$, A. Lankreijer ${ }^{2}$, and D. Nieuwland ${ }^{2}$ \\ ${ }^{1}$ Institut de Physique du Globe de Strasbourg, UMR 7516, 5. Rue René Descartes, 67084 Strasbourg, France \\ ${ }^{2}$ Faculty of Earth and Life Sciences, Vrije Universiteit, De Boelelaan 1085, 1081 HV Amsterdam, Netherlands
}

Received: 10 December 2001 - Accepted: 20 June 2002

\begin{abstract}
This paper presents the results of a new type of analogue model for prograding strike-slip faulting. In this model a small pre-existing basement fault is subjected to a strike-slip type stress field and allowed to prograde naturally into the homogeneous material. We used X-ray computer tomographic scanning to monitor the development of faulting in the model. The model shows the formation of coulomb shears at the tip of the fault. These coulomb shears all bendoff towards the receding block of the model, as is predicted by the theory. The shears are formed one after the other and abandoned splays are activated in a normal sense. On top of the basement layer, a second, weaker layer is applied to represent the sedimentary cover. We see the development of a pop-up structure above the pre-existing part of the basement fault. The normal movement on the abandoned splays of the growing fault make that a small pull-apart basin is formed at the location of the tip of the pre-existing basement fault. The complex history of the Pannonian Basin includes the formation of different structural lineaments in the earth' crust. The activation of some of these structures under the present-day stress conditions makes the basin an ideal study area to study the growth of reactivated faults. The model is compared to the results of a shallow high-resolution seismics survey and a small field campaign in western Hungary, where we studied segments of the Balatonfö fault. On the basis of the seismic activity and similarity between our model and the observations on the seismic sections and in the field, we conclude that active propagation of a segment of the Balatonfó fault is going on in the region.
\end{abstract}

Key words. Analogue modelling, strike-slip, Pannonian Basin, shallow seismics, geomorphology

Correspondence to: G. Lopes Cardozo

(lopes.cardozo@eost.u-strasbg.fr)

\section{Introduction}

Studies have been made of the vertical growth of strike-slip faults. Often, two base plates sliding alongside each other are used to reflect a basement fault in analogue strike-slip models. The position of the fault zone is fixed between the moving plates in those experiments (see Richard et al. (1995) and Casas et al. (2001) for an overview). This fixed position makes it impossible to monitor the growth of the fault in the horizontal plane. We built a model to monitor relation between the horizontal growth of strike-slip faults and the topographic expression resulting from this process. The purpose of this modelling is not to quantify the amount of tectonic movement in the region, but to study the processes at prograding fault tips and the surface expression of these processes. Monitoring of the fault pattern gives insight in the growth of the strike-slip fault. Regions of uplift and subsidence are defined to see how the fault growth could influence the geomorphology. We compare the results of the modelling with geomorphological observations in the field and highresolution $21 / 2 \mathrm{D}$ shallow seismics.

The active neotectonic development of a region in western Hungary is the subject of this study (see Figs. 1 and 2). More knowledge of this region is required because of the recent occurence of minor earthquakes (Tóth et al., 2002). A larger event with a magnitude $4.7 \mathrm{~m}_{b}$ shook the town of Berhida in 1985 (Tóth et al., 1989). Our interest focusses mainly on the recent activity of the Balatonfó fault. From seismic survey, this fault is known to be situated underneath Lake Balaton (Vida et al., 2001; Lopes Cardozo et al., 2001). The fault forms a part of the larger Balaton line. This ENE-WSW striking structure is activated in a compressive left lateral strike-slip setting under the present-day stress conditions in the region with a roughly N-S to NE-SW maximum horizontal compression (Bada, 1999; Bada et al., 2001). The study area lies at the foot of the Transdanubian Mountain Range. 


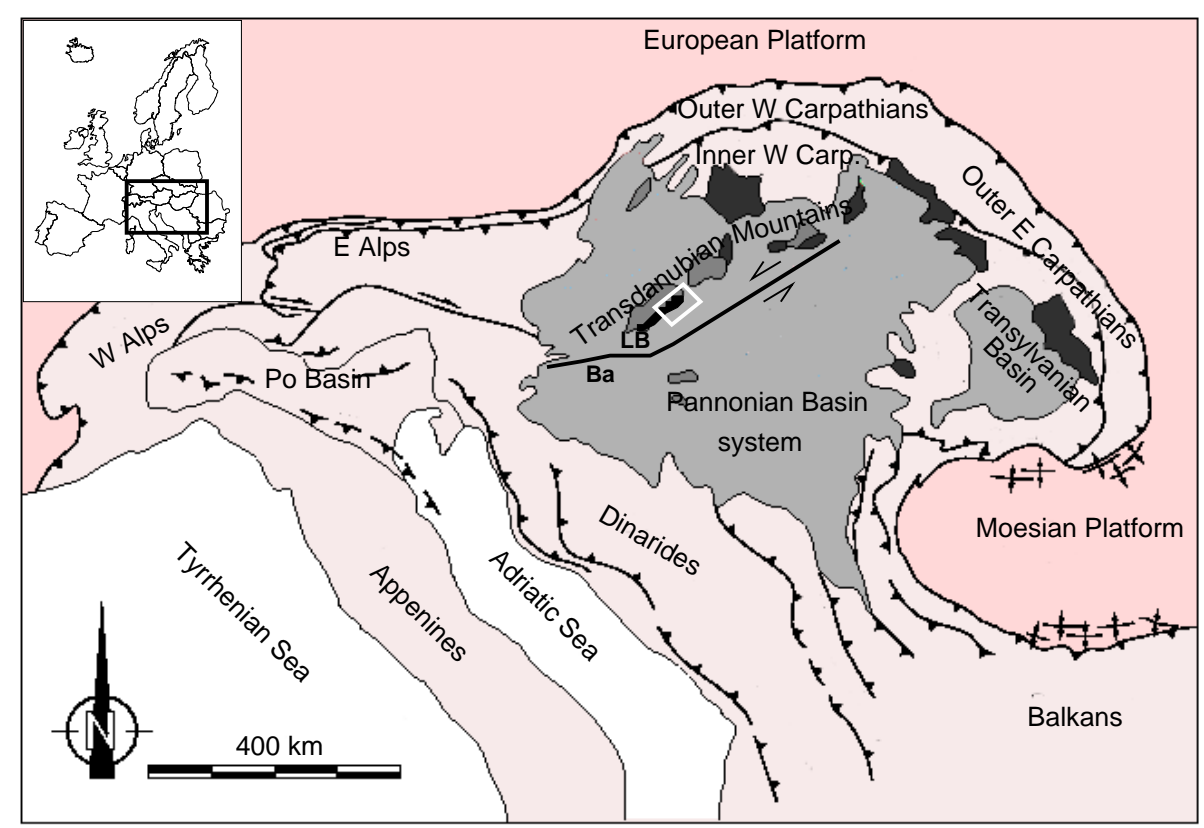

Fig. 1. Simplified map showing the structural setting of the Pannonian Basin system within the Alpine-Mediterranean region. The Pannonian system is bounded in the west by the eastern Alps, in the north and east by the Carpathian arc and in the south by the Dinaride system. Dark grey patches within the basin mark neogene vulcanics. $\mathrm{BA}=$ Balaton line, $\mathrm{LB}=$ Lake Balaton. White box in the NE corner of Lake Balaton shows the study region (Fig. 2). Fig. 1 based on map taken from the PANCARDI website (Decker et al., 1998).

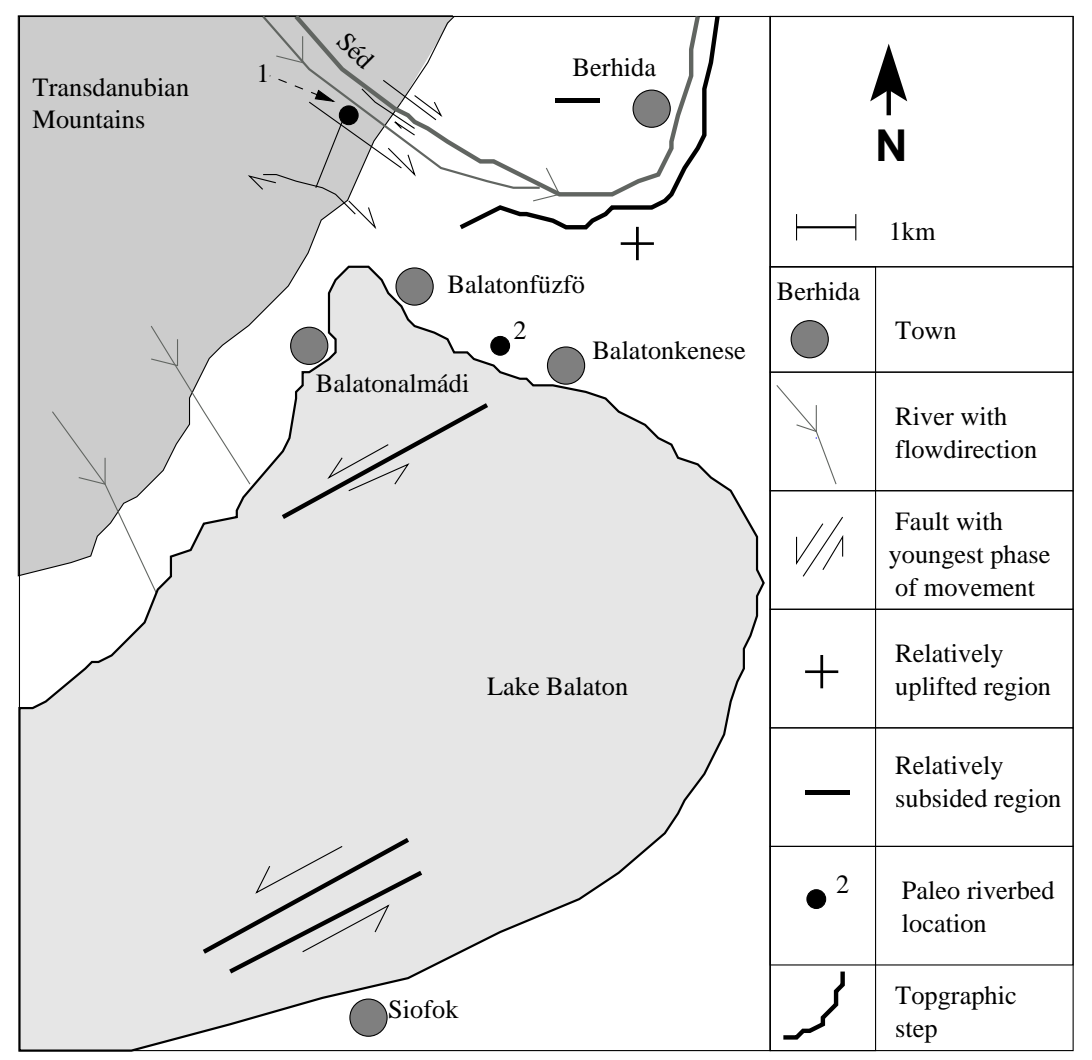

Fig. 2. simplified map of the study region. The thick black lines underneath Lake Balaton show the positions of known segments of the Balatonfő fault. The thick black line east of the town of Berhida indicates the position of an aproximately $40 \mathrm{~m}$ high topographic step. Along this step the river Séd (indicated in dark grey) bends off towards the north. 
The Quaternary uplift of this Mountain Range is estimated to be in the order of several hundereds of meters (Pécsi et al., 1984).

The recent tectonic activity of the Pannonian basin is controlled primarily by the counter clockwise rotation of the Adriatic microplate relative to Europe around a pole in the western Alps (Philip, 1987; Bada et al., 1998). The presentday kinematics of the Pannonian basin show that the area is pushed from the south-southwest (Bada et al., 2001). As a result, strike-slip to compressive faulting is observed inside the Pannonian basin (Fodor et al., 1999; Gerner et al., 1999). Furthermore, the nearly complete absence of normal faulting in the whole study area suggests that extension in the Pannonian basin has been terminated and structural inversion is in progress. The Quaternary subsidence and uplift history reflects large-scale bending of the Pannonian lithosphere. This bending is due to the increase of intraplate compressional stress (Horváth and Cloetingh, 1996). A high level of intra plate seismicity and neotectonic reactivation of pre-existing faults also indicates that the Pannonian basin is strongly affected by tectonic coupling with the surrounding African European collision system (Cloetingh, 2001).

The sedimentological record of the Pannonian Basin is extensively described by Steiniger et al. (1988). The sedimentology in the region is complex and Steiniger et al. (1988) have made an extensive study to correlate the Paratethys stages found in the Pannonian basin with the standard chronostratigraphy stages as they were published by Berggren et al. (1995). This correlation is shown in Fig. 3. The Pannonian to Pontian strata have a maximum thickness of about $200 \mathrm{~m}$ and unconformably overlie Sarmatian limestones underneath the lake. Sacchi et al. (1999) find transgressive system tract deposits of the Szák formation at the lowermost part of the Pannonian to Pontian sequence. This formation is topped by the Somló formation and the lower part of the Tihany formation that form highstand systems tract deposits. The rest of the Tihany formation is supposed to develop in nearshore areas at shallow depths. The Szák formation consists of clay-marl and siltstones, the Somló formation of deltaic deposits and the Tihany formation consists of near-shore deposits such as sands, silts, clay and calcretes. The Tihany formation is unconformably overlain by Pleistocene and Holocene lake sediments.

\subsection{Fieldwork}

A fieldwork was conducted in the region northeast of Lake Balaton. Several faults were identified as recently active on the basis of deformation of Quaternary sediments (see Fig. 2). The number of outcrops in the region is small and a reliable paleostress analysis could not be made. Still, we found that roughly NW-SE trending faults have a dextral youngest phase of movement and NE-SW trending faults have a sinistral sense of their youngest movements. We therefore infer that the N-S to NNE-SSW orientated maximum horizontal compression as is observed by Gerner et al. (1999) and modelled by Bada et al. (2001) is appropriate for

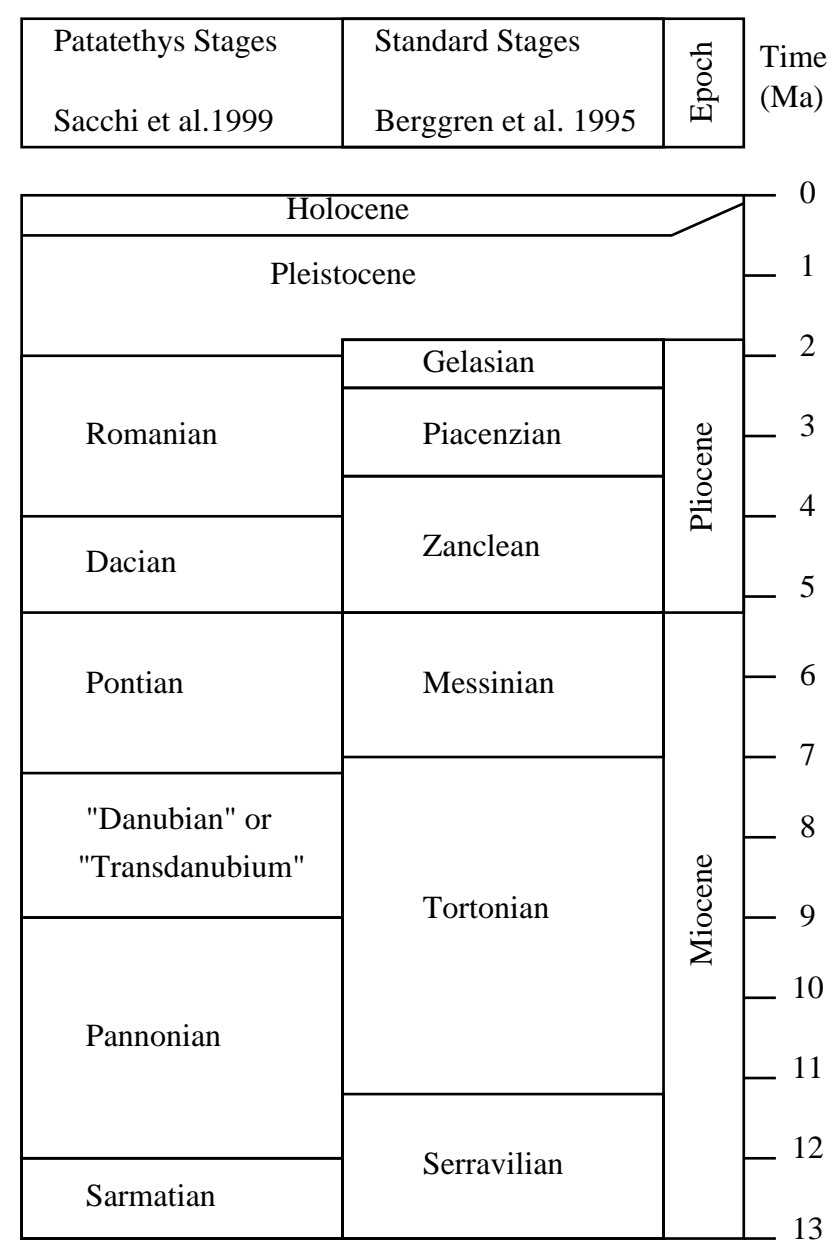

Fig. 3. The stratigraphic subdivision of the Paratethys stages compared to the standard Tethys stages.

this region. In the geomorphology of the region we find that there is a watershed between Lake Balaton and the Séd river (Fig. 2). The river has a present day path that runs off the Transdanubian Mountains in a SE direction in the direction of the lake. However, it bends off and continues its path towards the east. Finally, the river bends off along a steep topographic step towards the north, away from the Lake. We found an abandoned river incision (marked 1 in Fig. 2) wich is directed towards the lake. Furthermore, we found a Quaternary river delta (marked with 2 in Fig. 2) in the northwestern shore of Lake Balaton at a height of about $40 \mathrm{~m}$ above the lake. The paleo flow direction of this river was towards the lake. The sediments in this small conglomerate fan are the erosional products of the Transdanubian Mountains, they therefore postdate the beginning of the uplift of these mountains. We argue that once during the Quaternary there were rivers flowing from the northeast into the lake at its northeast shore. Apparently, there has been a substantial amount of vertical motions between the area in which the town of Berhida is situated and the higher area southeast of the topographic step (see Fig. 2). This Quaternary uplift caused a watershed between the Lake and the lower region of Berhida. 


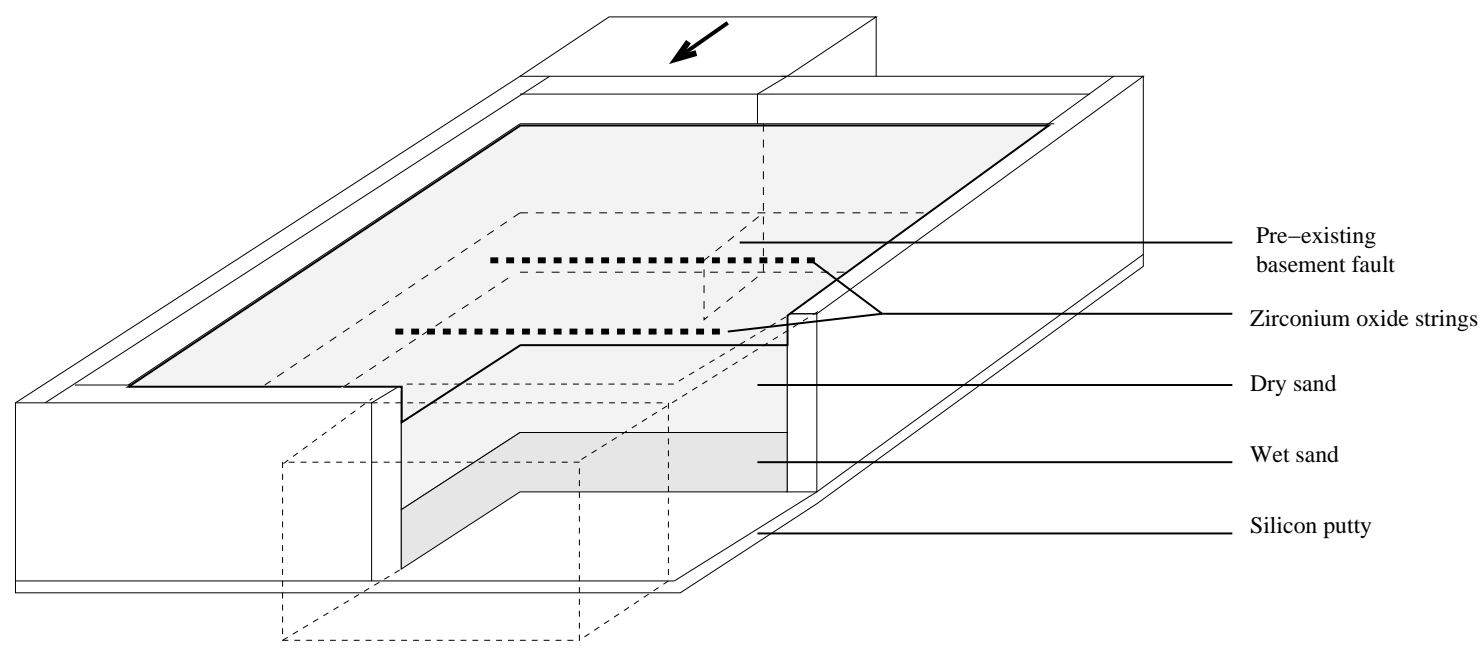

Fig. 4. The analogue model set-up, see text for discussion.

However, since we have no exact dating of the Quaternary sediments, we can not define the timing of this event. The segments of the Balatonfó fault as they are known from previous seismic surveys (Vida et al., 2001) are reactivated during the Quaternary and seem to terminate at the border of Lake Balaton. The onshore continuation of these large ENEWSW trending faults has not been found in the in the field. We assume that reactivation of segments in the fault zone under the present day stress conditions caused a growth of the faults towards the lake shore. With the help of an analogue model of active fault propagation we try to find if the observed vertical motions in the region NE of Lake Balaton could be the result of reactivation of basement faulting.

\section{Analogue model set-up}

The model consists of two U-shaped frames that form the sides of an enclosed box (see Fig. 4). The two frames are pushed so that the open sides slide alongside each other. Movement is only possible in one horizontal direction. By moving the frames, the material inside the box is deformed in a strike-slip sense. An electrical engine is used to run the model with a constant speed of approximately $2 \mathrm{~cm}$ per hour. The dimensions of the box are $20 \times 25 \mathrm{~cm}$.

The sand inside the box represents the Sarmatian limestone basement and the Pannonian to Quaternary sediment cover. The strength of the basement limestones exeeds that of the overlying unconsolidated sediments. To adequately model this difference in strength, two layers are made in the model. The lowermost layer, representing the Sarmatian basement, is made of wet sand. The amount of water is just sufficient to fill the spaces between the grains, but not enough to fill the pores. This capilary water causes a greater cohesive strength between the grains and thus a greater strength of the material. The upper layer, representing the sediments, is made of dry and finer sand. A zone of weakness, representing the pre-existing part of the basement fault, is created in the basal layer of the model. Cutting the sand in this layer before wetting it creates a zone of dilatation in the material. After spraying the sand with water, the dilated zone remains weaker than the surrounding material. The cut is made using a nylon wire and has a length of $5 \mathrm{~cm}$. It runs in between the two frames (See Fig. 4). To exclude the effect of friction at the base, the model is put on a silicon-putty floor.

The problem when monitoring strike-slip faulting in analogue models is that the faults are nearly invisible. The horizontal offset is very limited and introducing layers of coloured sand in the model does not help to visualise the horizontal displacement in cross sections. To tackle the problem of visualisation we used an X-ray computer tomographic scanner. This scanner, developed for medical use, can detect very small differences in density. Faults produce by their movement a dilatation in the sand, causing a lower density of the material. Using the scans, we were able to trace fault growth very acurately. High density Zirconium Oxide markers were inserted across the model, perpendicular to the direction of movement at different depths (as indicated in Fig. 4). From the deformation of these strings, we are able to monitor the horizontal displacement at different depths.

\section{Analogue modelling observations}

An interpretation is made on the basis of computer tomographic scans of the model during deformation (see Figs. 5 and 6). Fig. 5 gives a map view of the model at the depth of the contact between the wet basement sands and the dry cover sands. Faulting takes place first in the original orientation of the pre- existing fault. After $6 \mathrm{~mm}$ of deformation, a clear bend-off (marked 1 in Fig. 5) can be seen towards the receding block. As this coulomb shear grows, its direction becomes unfavourable for movement under the applied stress, and the splay dies out. After $8 \mathrm{~mm}$ of deformation a clear second coulomb shear is observed (marked 2 in Fig. 5). If deformation continues, this splay is activated in a normal 


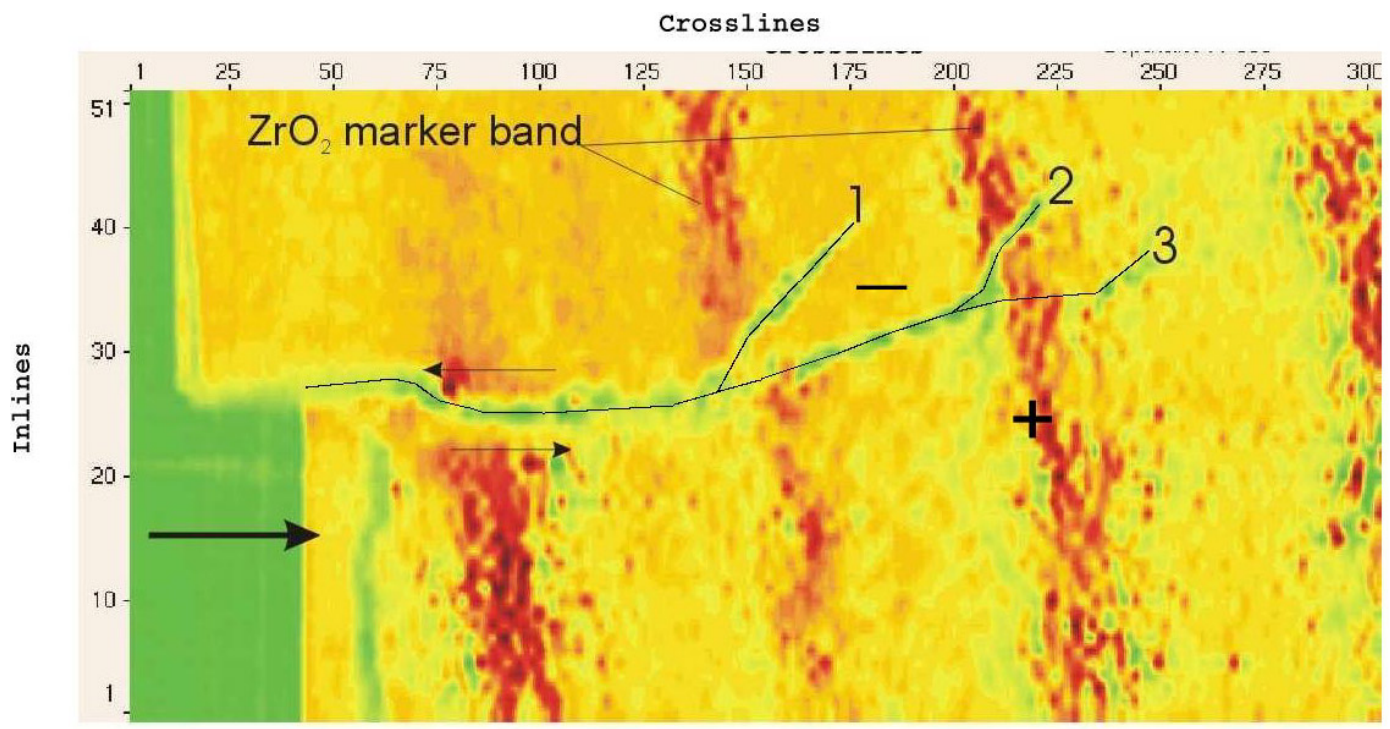

Fig. 5. Depth slice through the X-ray computer tomography of the model at the depth of the wet-dry sand boundary after $1.5 \mathrm{~cm}$ of displacement. The colour scale represents the density of the material. Low densities are in green, intemediate densities in yellow and high densities in Black. The Zirconium oxide has a very high density and the $\mathrm{ZrO}_{2}$ strings come out as thick black lines. Thin black lines show the positions of the faults, 1,2 and 3 are the first, second and third formed coulomb shears respectively. - marks a zone of subsidence, relative to the zone marked +. One crossline corresponds to $0.5 \mathrm{~mm}$ for scaling.
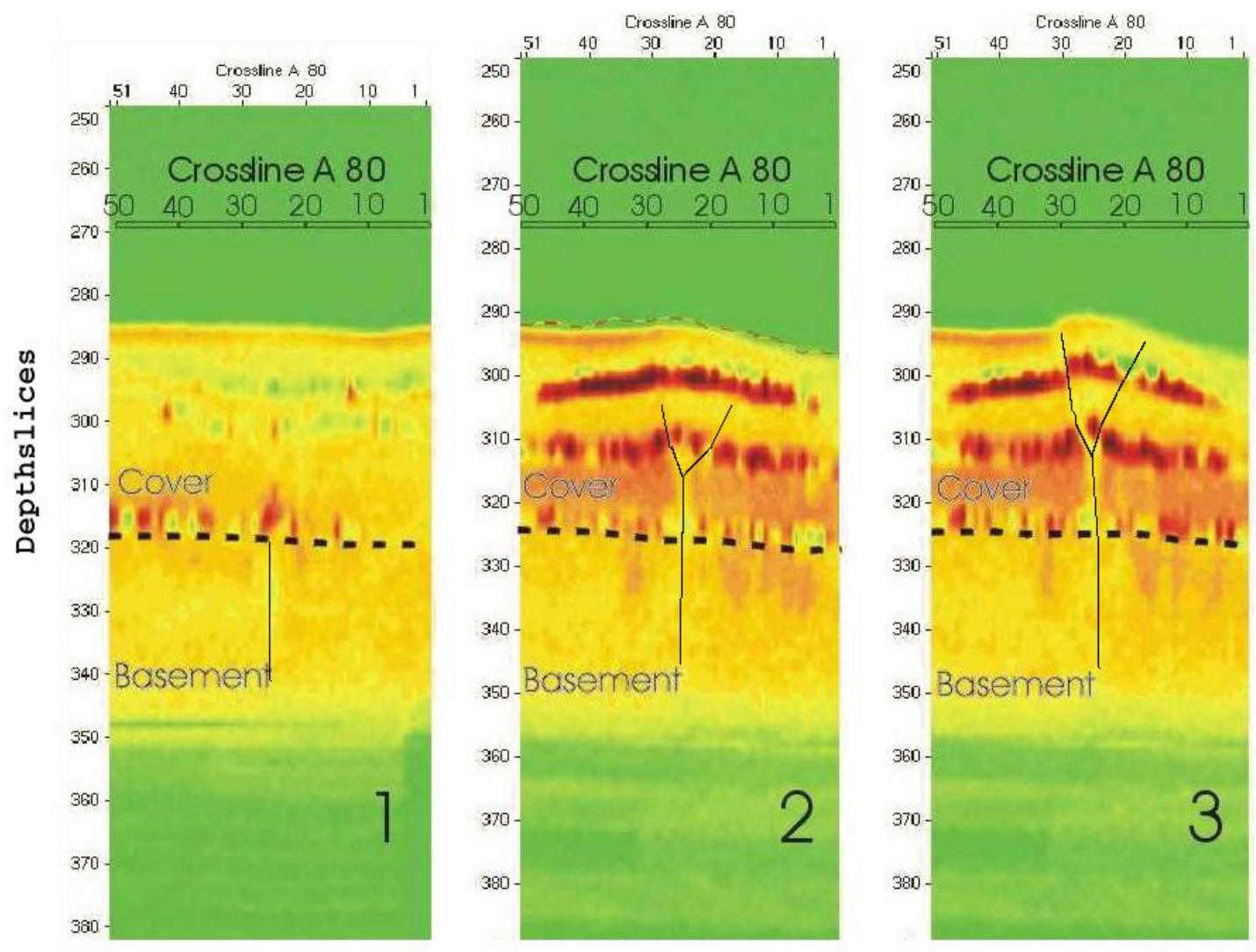

Fig. 6. Cross sections through the X-ray computer tomography of the model after $0,0.6$ and $1.5 \mathrm{~cm}$ of displacement. The position of the crosslines is at the tip of the pre-existing fault. Colour code is the same as in Fig. 5. One depthslice corresponds to $0.5 \mathrm{~mm}$ for scaling. See text for discussion. 


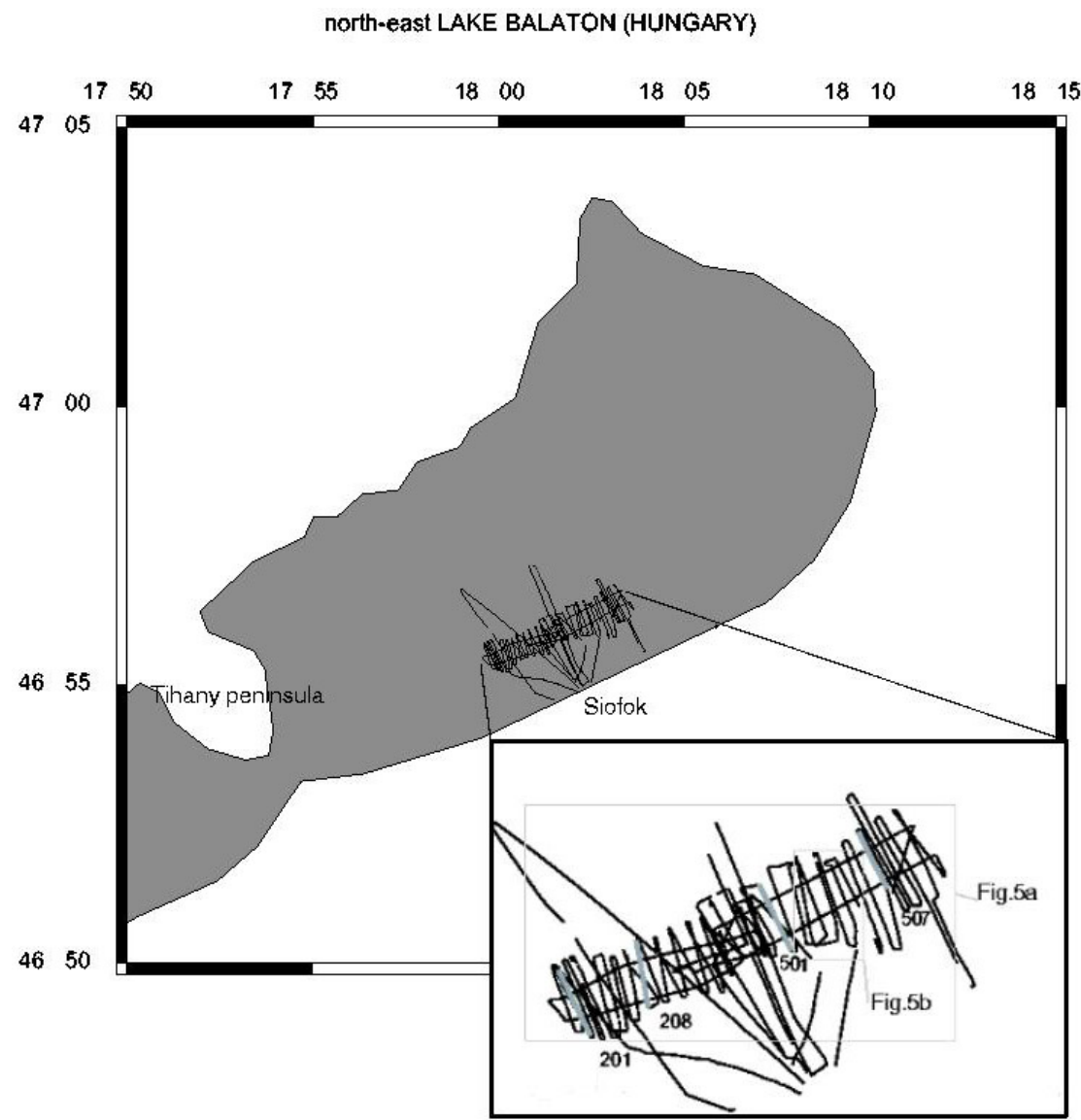

Fig. 7. Position of the seismic lines on Lake Balaton. A very dense grid of lines is shot over the position of a known segment of the Balatonfö fault. Insert shows the position of the lines shown in Fig. 8 and grey boxes in the insert show the position of the time contour maps in Fig. 9. sense under the applied stress. In the end, a clear horsetailstructure has formed at the tip of the pre-existing basement fault. Fig. 6 shows crosslines through the model at the tip of the pre-existing fault. In Fig. 6.2, clear faulting in the basement can be seen, but the faulting does not reach the surface and the overlying sediments are folded. After $1.5 \mathrm{~cm}$ of deformation, clear faulting in the sediments can be observed (Fig. 6.3) and this faulting is continuous to the surface. A positive flower structure developed in the sediments above the pre-existing basement fault. Faulting of the sediments takes place in two distinct zones with a popped-up zone in between. Further observations come from cutting the model directly after the deformation. Folding and thickening of the sediments creates distinct topography. The uplift and subsidence in the model can create surface undulations with a height up to several milimeters. In the central part of the model the sediments are folded and locally small thrusts are formed.

It is interesting to see that the progressing basement fault does not grow along the straight line between the frames in the homogene basement material. If deviation from the straight line occurs, the fault bends in the direction of the receding block. The bending in this direction is explained in Mandl (2000, Ch. 7). When movement takes place on the fault, the confining stresses in the proceding block are increased. At the same time, these confining stresses drop in the receding block. This drop in confining stresses causes the material in the receding block to break sooner than the material in the proceding block.

\section{Single channel high-resolution shallow seismics on Lake Balaton}

To test the validity of the model, we compare it with the results of single channel ultra-high resolution seismic survey that was conducted on Lake Balaton (see Fig. 7 for the position of the seismic lines). This method has already been applied succesfully in intra-continental settings, mainly in riverine environments and lakes (Tóth et al., 1997). The objective of this survey was to image the upper $40 \mathrm{~m}$ of the Balatonfö fault underneath Lake Balaton. On deeper seismic sections we see that one single fault cuts through the Sarmatian limestones underneath this part of the lake. Although the fault may be continuous, the recently activated part of the fault seems to terminate in the northeastern part of the lake (Lopes Cardozo et al., 2001; Vida et al., 2001).

To acquire the data, a high-resolution subbottom profiler was used (Simpkin, 1999; Mosher and Simpkin, 1999; Tóth et al., 1997). This equipment has a boomer source that has a diameter of $38 \mathrm{~cm}$. This source has a broad frequency band of $1-10 \mathrm{kHz}$. The source is mounted on a catamaran together 
Line 201

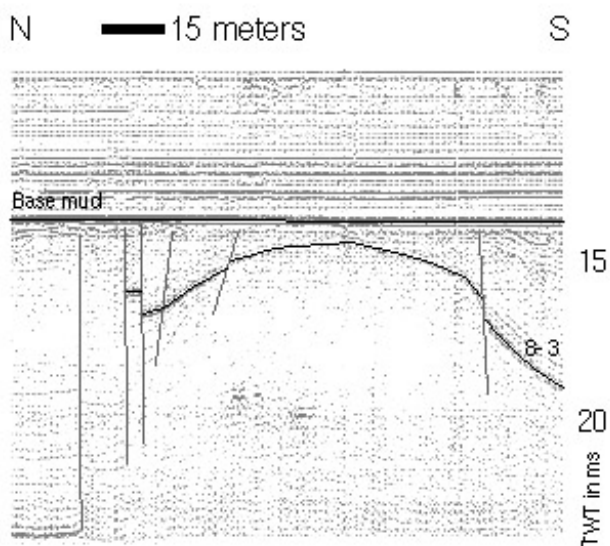

Line 501

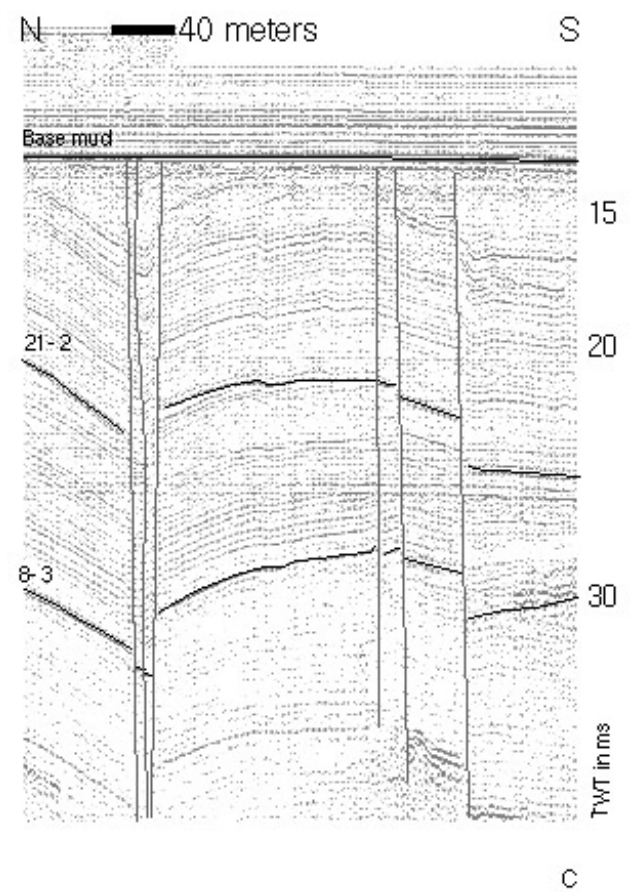

Line 208

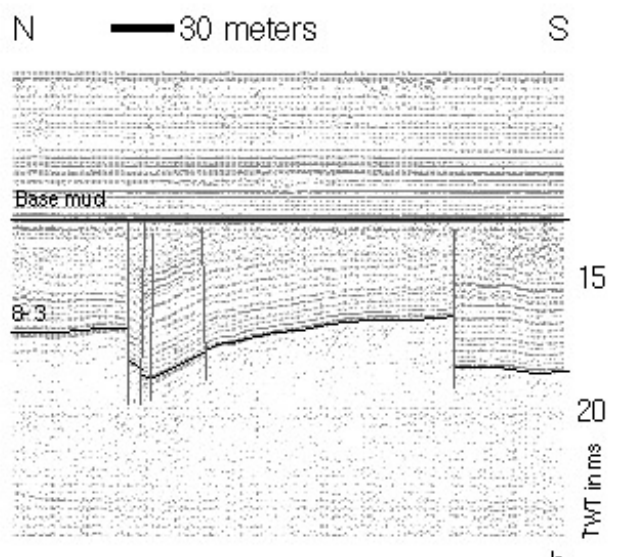

b

Line 507

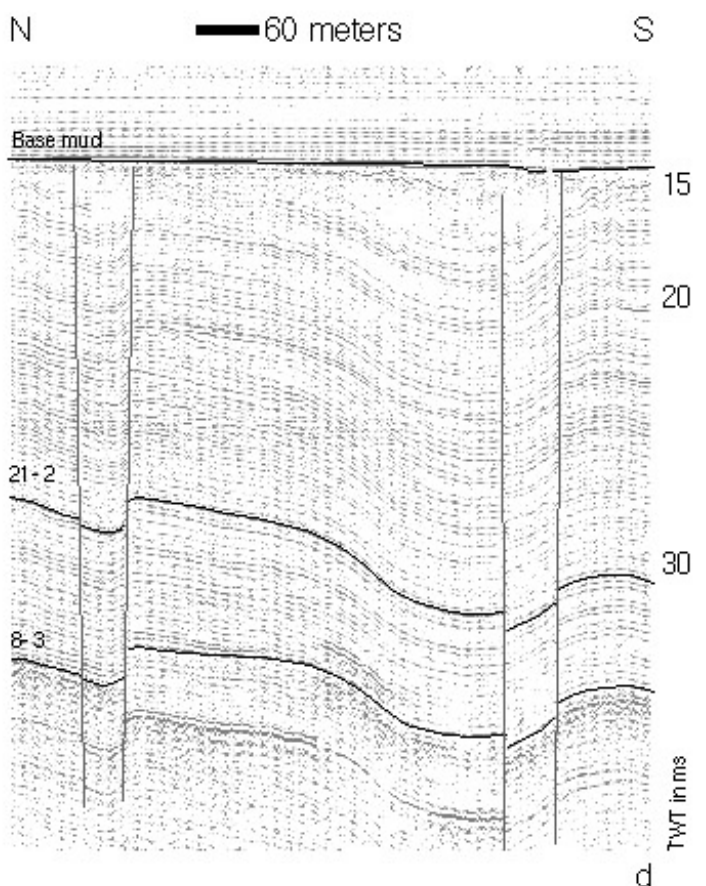

Fig. 8. Examplary lines crossing the two fault zones that form the near surface expression of the segment of the Balatonfö fault. Black lines show the traced horizons, grey lines show the position of interpreted faults. The vertical exageration is in the order of 6 times. See Fig. 7 for positions.

with a 6-element hydrophone. The hydrophones are closely spaced to allow sampling of the high frequency signal. By mounting source and receiver on the same frame, the distance between them is fixed at $70 \mathrm{~cm}$. This fixed position allows for a high resolution in shallow water depths. The close spacing between the lines allows for a pseudo $3 \mathrm{~d}$ interpretation. With the high resolution, in the order of $10 \mathrm{~cm}$, it is possible to define young structures with limited offset. A total of five horizons has been defined and tracked within the depth range of the seismics. Exact calibration of the horizons with the stratigraphy was not possible because none of the horizons could be traced over a borehole. On the basis of the seismic characteristics (Sacchi et al. (1999) and personal communication) we conclude that four of these horizons lie in the Tihany and Somló formations, the fifth horizon marks the base of the Holocene deposits.

Figure 8 shows four selected seismic sections (see positions in Fig. 7). In the survey area, the faulting is defined to two ENE-WSW trending fault zones. This division is made on the base of similarity between the fault zones as they are seen on the seismic sections. No deformation is observed above the base mud horizon. 


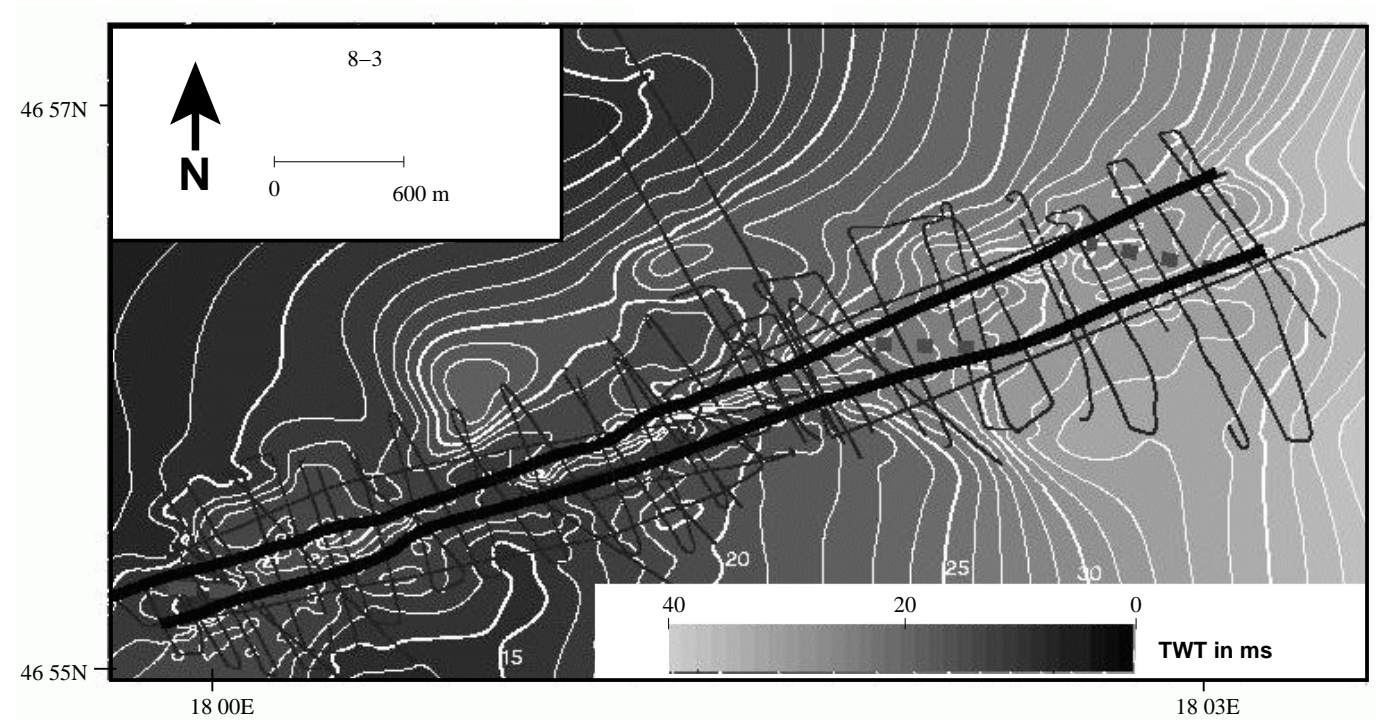

(a)

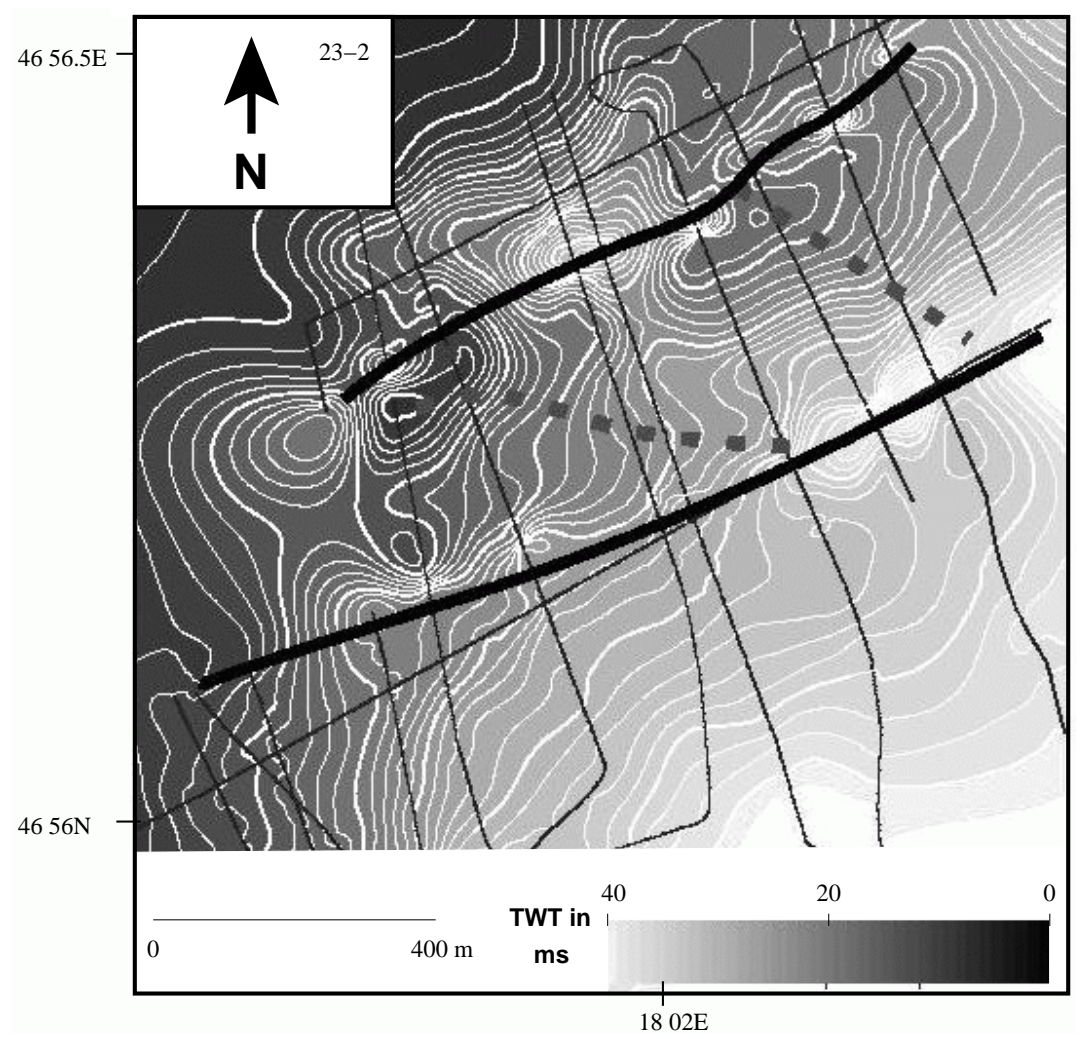

(b)

Fig. 9. Time contour maps of two different horizons (see Fig. 7 for position) Thick black lines show the position where the faults cut the displayed horizon. Grey dotted lines show fold axes of faults in the uplifted block between the two fault zones. Note that the data is constrained to the position of the lines and is interpolated outside the grid. See text for discussion.

After interpretation of the sections, two way travel time contour maps were made (shown in Fig. 9, see Fig. 7 for the position of these maps). One of these contour maps can be seen in Fig. 9a. This map gives an overview of the contours of horizon 8.3 that could be traced over the entire sur- vey. The position of the fault zones is defined independent from the contour plots. Figure 9a clearly shows an overall dip towards the east of the interpreted horizon. This tilting of the horizon away from the Transdanubian Mountain Range is thought to be related to the late stage uplift of this moun- 
tain range (Pécsi et al., 1984; Horváth and Cloetingh, 1996). Over the whole length of the area lie two narrow depressions in the 8.3 horizon. The position of the intersections of two fault zones with the interpreted horizon corresponds with the depressions. Between the two fault zones, an uplifted zone can be seen. This higher part is not regular in shape, but seems to be folded over E-W to ENE-WSW fold axes (indicated in dark grey dotted lines). A clearer example of this folding can be seen in Fig. 9b, where we see a detailed time contour map of a horizon above the 8.3 horizon. Note that the real data are confined to the shotlines and the rest is interpolated.

\section{Discussion}

The results of our modelling correspond well to the observations of Casas et al. (2001) for the part above the pre-existing basement fault. The positive flower structure, with a pop-up separated by two distinct zones of faulting, is presented in their study as resulting from a transpressive strike-slip motion on a single basement fault. In analogue modelling it is common to model strike-slip faulting by movement of basal plates (Richard et al., 1995). This kind of models is useful only to model movement on a pre-existing basement lineament. The exact orientation and position of that basement lineament is fixed by the position of the basal plates. In our model, the position of the basement lineament is only fixed in a limited part of the model by the creation of a zone of weakness in the basment layer. The basement fault is therefore free to develop in its natural direction under the applied stress. The question remains whether our model can be applied to the region, since it is likely that the Balatonfo' fault zone is continuous over a longer distance. We should therefore note that we have only studied a limited, reactivated segment of this fault zone. This activated segment may not be the segment that formed the aim of our seismic campaign, since there seems to be an absence of faulting in the Holocene mud layer above the fault segment. In the upper $40 \mathrm{~m}$ of the studied part of the Balatonfó fault, two distinct zones of faulting exist. Since we know from pevious seismic surveys that the fault cuts the Sarmatian basement as a single fault, we conclude that these two zones of faulting are rooted on that fault. This positive flower structure corresponds very well to the observations from our analogue model for reactivation of a pre-existing basement fault. It is therefore likely that the Balatonfó fault was reactivated in a transpressive strike-slip sense after the deposition of the Pannonian and Pontian sediments. Because of the erosive truncation of these sediments and the absence of visible structure in the Holocene mud deposits, the exact timing of this faulting cannot be defined. If we compare our model to the geomorphological observations in the region northeast of Lake Balaton we find a striking coherence in the strike of fault splays in the model and geomorphological lineaments. The orientation of the second faultsplay corresponds well to the orientation of the topographic step east of the town of Berhida. Observed normal movement on this splay in the model could be responsible for this topography. Furthermore there is similarity between observed subsidence at the tip of the pre-existing fault and the position of topographically lower regions in the field. On the basis of the similarity between the geomorphology in the region northeast of Lake Balaton and our model, we conclude that it is likely that reactivation of a part of the Balatonfo" fault is responsible for this geomorphology. Since the Pannonian and Pontian sediments as they are found in the region northeast of Lake Balaton underwent only a limited amount of diagenesis and compaction, they are considered weak and easily erodable. The fact that these sediments form the watershed between the Séd river and Lake Balaton, could be an indication for very recent activity in the region. Further indications for present-day activity in the region come from the occurence of earthquakes (Tóth et al., 2002).

\section{Conclusions}

The results of the modelling experiment give insight in strike-slip fault propagation. In a situation where no lateral expansion is possible, the direction of growth of a reactivated basement strike-slip fault can not be a straight continuation of the original orientation of this fault. The tip of the fault bends off towards the receding block, forming coulomb shears at the fault tip. When a weak layer of sediments is imposed on a fault in a more rigid basement layer, it will develop its own faulting pattern. In our model, the faulting of the sediments takes place in two distinct zones above the pre-existing basement fault. As a result of the bending of the basement fault after reactivation, a pull-apart basin is formed at the tip of the pre-existing fault. In the rest of the model the sediments react by folding and thickening rather than distinct faulting. Our model helps to obtain additional information on the geology in a region where outcrops are very scarce. The good fit between the modelled situation above the pre-existing basement strike-slip fault and the observations on seismics shows that the studied segment of the Balatonfó fault was reactivated in a transpressive setting. On the basis of the similarity between our model and the observed geomorphology in the region northeast of Lake Balaton it seems likely that reactivation and propagation of a segment of the Balatonfö fault takes place at the moment. The observed formation of new coulomb shears in the model gives a reasonable explanation for the seismic activity in the region northeast of Lake Balaton.

Acknowledgements. The authors are endebted to Dr. Fodor (Budapest) for his guidance in the field and stimulating discussions. Prof. Horváth (Budapest), Prof. Cloetingh and Dr. Bertotti (Amsterdam) are thanked for fruitfull discussions. The high resolution survey was carried out in the framework of Eurobasin event X. Robert Vida kindly provided the seismic sections presented. The manuscript benefitted from thorough remarks by Christophe Pascal and an anonymous reviewer. 


\section{References}

Bada, G.: Cenozioc stress field evolution in the Pannonian basin and surrounding orogens, Ph.D. thesis, Vrije Universiteit, Amsterdam, 1999.

Bada, G., Cloetingh, S. A. P. L., Gerner, P., and Horváth, F.: Sources of recent tectonic stress in the Pannonian region: inferrences from finite element modelling. Geophysical Journal International 134, 87-101, 1998.

Bada, G., Horváth, F., Cloetingh, S. A. P. L., Coblentz, D., and Tóth, T.: Role of topography-induced gravitational stresses in basin inversion: The case study of the Pannonian basin, Tectonics, 20, 343-363, 2001.

Berggren, W. A., Hilgen, F. J., Langereis, C. G., Kent, D. V., Obradovich, J. D., Raffi, I., Raymo, M. E., and Shackleton, N. J.: Late Neogene chronology; new perspectives in high-resolution stratigraphy, Geological Society of America Bulletin, 107, 11, 1272-1287, 1995.

Casas, A. M., Gapais, D., Nalpas, T., Besnard, K., and RománBerdiel, T.: Analogue models of transpressive systems, Journal of Structural Geology, 12, 733-743, 2001.

Cloetingh, S. A. P. L.: Lithospheric memory and stress field controls on polyphase deformation of ther Pannonian basin - Carpathian system, Marine and Petroleum Geology, 18, 3-11, 2001.

Decker, K. E., Lillie, R. E., and Tomek, C. (Eds.): PANCARDI; the lithospheric structure and evolution of the Pannonian/Carpathian/Dinaride region, Tectonophysics, 297, 1-293, 1998.

Fodor, L., Csontos, L., Bada, G., Gyorfi, I., and Benkovics, L.: Tertiary tectonic evolution of the Pannonian Basin system and neighbouring orogens; a new synthesis of palaeostress data, in: Durand, B., Jolivet, L., Horváth, and F., Seranne, M. (Eds.): The Mediterranean basins; Tertiary extension within the Alpine Orogen. Vol. 156 of Geological Society Special Publications, Geological Society of London, London, UK, 295-334, 1999.

Gerner, P., Bada, G., Dovenyi, P., Mueller, B., Oncescu, M. C., Cloetingh, S. A. P. L., and Horváth, F.: Recent tectonic stress and crustal deformation in and around the Pannonian Basin; data and models, in: Durand, B., Jolivet, L., Horváth, F., and Seranne, M. (Eds.): The Mediterranean basins; Tertiary extension within the Alpine Orogen, of Geological Society Special Publications, Geological Society of London, London, UK, 156, 269-294, 1999.

Horváth, F. and Cloetingh, S. A. P. L.: Stress-induced late-stage subsidence anomalies in the Pannonian basin, Tectonophysics, 266, 287-300, 1996.

Lopes Cardozo, G., Bada, G., and Nieuwland, D.: Neotectonic strike-slip movements in western hungary: From field study through shallow high-resolution seismics towards an analogue model, Abstract book Stephan Mueller Topical conference of the European Geophysical Society., 2001.

Mandl, G.: Faulting in brittle rocks, Springer, Berlin-Heidelberg, 2000.

Mosher, D. C. and Simpkin, P. G.: Environmental marine geoscience; 1, Status and trends of marine high-resolution seismic reflection profiling; data acquisition, Geoscience Canada, 26, 174-188, 1999.

Pécsi, M., Schweitzer, F., and Schauer, G.: Ploi-Pleistocene tectonic movementsand the travertine horizons in the Hungarian Mountains, Stusia Geomorph, Carpatho-Balcanica, 17, 19-26, 1984.

Philip, H.: Plio-Quaternary evolution of the stress field in Mediterranean zones of subduction and collision, Ann. geophys., 5, 301320, 1987.

Richard, P. D., Naylor, M. A., and Koopman, A.: Experimental models of strike slip tectonics, Petroleum Geoscience, 1, 71-80, 1995.

Sacchi, M., Horváth, F., and Magyari, O.: The role of unconformity-bounded units in stratigraphy of continental record: a case study from the late Miocene of western Pannonian basin, Hungary, in: Durand, B., Jolivet, L., Horváth, F., and Seranne, M. (Eds.): The Mediterranean basins; Tertiary extension within the Alpine Orogen, Geological Society Special Publications, Geological Society of London., UK, 156, 357-390, 1999.

Simpkin, P.: The IKB-Seistec Sub-Bottom Profiler. Tech. rep., IKB Technologies limited, Nova Scotia, Canada, 1999.

Steiniger, F., Müller, C., and Rögl, F.: Correlation between Central Paratethys, Eastern Paratethys and Mediterranean stages, in: Royden, L. and Horváth, F. (Eds.): The Pannonian Basin: a study in basin evolution, AAPG Mem., 45, 79-87, 1988.

Tóth, L., Mónus, P., and Zsíros, T.: The Berhida (Hungary) earthquake of 1985, Gerlands Beitr. Geophysik, 98, 312-321, 1989.

Tóth, L., Mónus, P., Zsíros, T., and Kiszley, M.: Seismicity in the Pannonian basin: Earthquake data, in: Cloetingh, S. A. P. L., Horváth, F., Bada, G., and Lankreijer, A. (Eds.): Neotectonics and seismicity of the Pannonian Basin and surrounding orogens, a memoir on the Pannonian Basin, European Geosciences Union, (this vol.), 2002.

Tóth, T., Vida, R., Horváth, F., and Simpkin, P.: Shallow-water single and multi-channel seismic profiling in a riverine environment, Leading edge Nov. 1997, 1691-1695, 1997.

Vida, R., Tóth, T., Szafián, P., Fekete, N., Dövényi, P., and Horváth, F.: Ultra-high resolution seismic mapping of a strike-slip faultsystem, Abstract book Stephan Mueller Topical conference of the European Geophysical Society, 2001. 